\title{
Multivariate Analysis of the Condition of the Property Development Sector: Selected Local Real Estate Markets in the European Union
}

\author{
Iwona Forys $^{1}$ - Malgorzata Tarczynska-Luniewska ${ }^{2}$
}

Published online: 1 February 2018

C) The Author(s) 2018. This article is an open access publication

\begin{abstract}
The aim of the study is to serve as a multidimensional analysis of relationships between the economic and financial standing of property developers and the residential property market situation. The discussion concerns the property development market situation in the context of the construction market situation, with particular emphasis on residential housing investment in selected EU countries. Property development companies whose activities focused on residential housing were assessed with respect to performance in the selected market on the stock exchange. Individual companies were classified using economic and financial indices. Despite the ongoing economic downturn in real estate markets, the results for these companies did not indicate poor performance on the stock exchange. In the study, a synthetic measure of development was used in linear ordering.
\end{abstract}

Keywords Multivariate analysis $\cdot$ Property development $\cdot$ Real estate market

JEL $\mathrm{G} 12 \cdot \mathrm{L} 74 \cdot \mathrm{R} 15 \cdot \mathrm{R} 31$

\section{Introduction}

The economic downturn in the real estate market in Europe, as on other continents, began in the second quarter of 2008. Fast transition of adverse economic factors, associated with the economic crisis across national borders and local economies, was

Malgorzata Tarczynska-Luniewska

maluni@poczta.fm

1 Department of Operations Research and Applied Mathematics in Economics, Faculty of Economic and Management, University of Szczecin, ul. Mickiewicza 64, 71-101 Szczecin, Poland

2 Department of Statistics, Faculty of Economic and Management, University of Szczecin, ul. Mickiewicza 64, 71-101 Szczecin, Poland 
the result of globalization and transnational economic systems. It was also the result of the emergence of multinational corporations, whose scope covered a number of countries on all continents. Above all, the globalization of financial markets, and other related markets, caused the current global crises to be deep and spatially extensive, affecting many areas of socioeconomic life.

As shown by the recent global crisis, the real estate market is an important segment of the economy because it both affects and is affected by the financial sector. It is the crisis in the financial markets, defined as episodes of rapid changes in the financial markets, connected with deficiency of liquidity or insolvency of market participants, that caused the global economic crisis in 2008 (Bordo et al. 2000). The dynamic development of modern financing instruments, conditioning debt repayment on the ability to enter into new commitments (refinancing) or a low level of investors' equity involvement in the real estate market, connected the discussed financial crisis with the real estate market (Minsky 1986).

The instability of the financial system, caused by increased lending of subprime mortgages, became the cause of the recent crisis in the U.S., which spread to other countries and continents. However, in some countries, signs of recovery from the crisis can be noted. ${ }^{1}$ Some questions arise: Was the unfavorable trend on the supply side for new apartments reversed? Can one talk about sustainable improvement of active property development companies?

The effects of adverse changes, both in the real estate and financial markets were felt by participants involved in real estate transactions. Most of the available publications link the crises in the real estate market, the banking sector, insurance sector, and financial markets. Few discuss the economic condition of individuals on the new investment supply side. Too seldom is research undertaken within the real estate market and on the impact that the crisis had for actors directly related with services in this market, such as property developers and the broadly understood construction industry (Peto 2011; Al-Malkawi and Pillai 2013).

However, investments in the housing market are most sensitive to changes in the economic environment and characterized by short business cycles. Hence the study of the housing market and developers serves as a barometer of the situation throughout the entire real estate market. It is clear that the economic downturn, including the slump in the real estate market, should have had a negative impact on the condition of property development companies. Financial results for these companies do not confirm the persistence of unfavorable trends for all European real estate markets.

Lack of investor confidence in the real estate market caused an outflow of capital and limited execution of new projects. The residential property segment, sensitive to signals from the capital market, the overall economy and households, strongly felt the economy deteriorating in 2008. How are development companies faring compared to in the real estate market? Is the performance of property development companies listed on the Warsaw Stock Exchange (WSE) (technical or short-term analysis) a good indicator of the actual financial condition of these firms? How do the financial results of the discussed companies (fundamental or long-term analysis) relate to it? The attempt to answer the

\footnotetext{
${ }^{1}$ This is evidenced by reports of consulting companies from local real estate markets (e.g. Cushman \& Wakefield). An interesting study taking into account trends in the European real estate market, is the study prepared by UBS managers (2015).
} 
above questions signals a new approach to the issue of economic downturn in the real property market.

The aim of this study is to evaluate selected local real estate focusing on the socioeconomic potential of housing markets and property development companies listed on the local stock exchange. A ranking of residential real estate markets has been created for these European markets that will indicate their development potential. For a selected market, a research hypothesis on the strong correlation between the condition of property development companies and the state of the housing market during the economic downturn in the real estate market was tested. For this purpose, basic economic and financial indices were used for classification and positioning of individual real estate markets. To test the hypothesis, multivariate methods of data classification were used. The results may help property development companies in investment decisions in international markets and may provide national authorities with clues to determine the cause of a weak position for a given country in an international ranking.

\section{Construction and Assembly Production: Housing Sector Results for Selected EU Countries ${ }^{2}$}

\section{Construction Production Index}

The research shows the situation in the housing market and property development sector in selected EU countries. In recent years, economic indicators suggest that changes have occurred in the housing market and its environment. In EU countries (EU-15 and EU-27), a sustained downward trend in construction production has been observed since 2007, which outpaced the 2008 economic crisis and the crisis in the real estate market. The price bubble that began as early as 2006 affected the value of the construction production index in subsequent years, which is related to the cycle of construction production and long-term contracts of property development companies.

Compared to 2009, when the crisis in the EU countries became a fact, the index value decreased in most countries, but increased in Germany, Lithuania, Poland, Finland, Sweden and the United Kingdom (Table 1).

One cannot predict the sustained reversal of the downward trend in construction production in the EU based on only one year's data, but such symptoms may have indicated an increased interest in the purchase of new dwellings in 2014. Since most dwellings are purchased with a mortgage, the increased number of long-term bank loans could have been a symptom of high demand in the housing market. A decrease in construction output should affect property development companies. In the long term, poor performance of these companies means more failures, which consequently affects construction outcome.

\footnotetext{
${ }^{2}$ All the statistical analyses in this chapter are based on Eurostat European Commission (2015) data.
} 
Table 1 Indices of the construction market and the housing market in selected countries

\begin{tabular}{lllll}
\hline Country & $\begin{array}{l}\text { Volume index } \\
\text { of production } \\
(2009-2014)\end{array}$ & $\begin{array}{l}\text { Condominium } \\
\text { debt } \\
(2009-2013)\end{array}$ & $\begin{array}{l}\text { Dwellings leased with } \\
\text { financial support } \\
(2009-2013)\end{array}$ & $\begin{array}{l}\text { Building permits - } \\
\text { number of dwellings } \\
(2010-2013)\end{array}$ \\
\hline Belgium & decrease & increase & increase & stagnation \\
Bulgaria & decrease & decrease & decrease & decrease \\
Czech Republic & decrease & increase & decrease & decrease \\
Denmark & decrease & decrease & stagnation & decrease \\
Germany & increase & stagnation & increase & increase \\
Ireland & decrease & increase & stagnation & decrease \\
France & decrease & increase & decrease & decrease \\
Lithuania & increase & decrease & decrease & increase \\
Hungary & decrease & increase & decrease & decrease \\
Poland & increase & increase & decrease & decrease \\
Portugal & decrease & increase & stagnation & decrease \\
Slovenia & decrease & increase & increase & decrease \\
Slovakia & decrease & increase & increase & decrease \\
Finland & increase & decrease & increase & decrease \\
Sweden & increase & increase & decrease & increase \\
United Kingdom & increase & decrease & increase & increase \\
\hline
\end{tabular}

Source: Compilation of the author based on Eurostat (2015) data

\section{Mortgaged Property}

The increased number of mortgaged dwellings meant that homebuyers in the market obtained funds on credit, which consequently improved the supply of new dwellings and performance of property developers. However, the decline in mortgaged housing was not synonymous with rapid repayment because the loans were long-term.

In 2013, countries referred to as the "old 15" saw an increase in the number of mortgaged dwellings (32\%), while in the EU-27 the level of mortgaged housing remained stable at 27-28\%, a constant since 2011. An interesting phenomenon was the opposite trend in the analysis of both groups of European countries from 2007 to 2010. In the EU-15, the number of mortgaged dwellings increased from 2005 to 2009, after which a downward trend could be seen. Fluctuations in mortgaged housing were small, between $31 \%$ and $33 \%$. Those processes in the housing market were not the same in all EU countries. Especially noteworthy were opposing trends in selected countries in 2013 compared to 2009 (Table 1).

A decrease in the index with respect to condominium debt was observed in Bulgaria, Denmark, Lithuania, Finland and the United Kingdom. Only in Germany did the level of mortgaged housing remain constant at $27.6 \%$ of the total of condominiums, while the largest share of mortgaged housing $(64 \%)$ occurred in Norway, and the smallest in Romania (1\%). Despite the crisis in the real estate market and the related demand for the purchase of dwellings in Poland, the mortgaged housing index remained unchanged from 2005 to 2012, and stabilized at $10 \%$ of the total housing. The opposite (decreasing) trend can be seen in the UK, where $38 \%$ of dwellings were mortgaged. 
On the other hand, construction and leasing were also assisted by the state. Lack of household creditworthiness increased interest in dwellings leased with financial support from the state. However, the economic downturn limited the budgets of the selected countries and state support for housing needs decreased. Thus, the share of dwellings leased with financial support from the state also decreased. The share of dwellings built with financial support from the state decreased faster in the EU-27 than in the EU-15, where the decline was less severe. However, in some countries the trend was the opposite or there were no significant changes at all, such as in Germany, Ireland and Portugal (Table 1). The largest proportion of dwellings leased with support from the state was in Slovenia (17.7\%), and the lowest was in the Netherlands (0.4\%). Apparently, governmental financial support for housing developments is always closely associated with the situation in the property market. Yet, such support invariably fosters the construction sector and property developers by encouraging demand for their services, and thus improving their financial performance.

\section{New Building Permits}

The condition of the residential housing market was evidenced by companies constructing new dwellings, and the expression of this activity was, among other things, permits issued for the such construction. In 2009-2011, there was no change in the number of housing permits in EU countries, while in 2012 and 2013 there was a decline of 19\%. In 2006, two-and-a-half times more housing permits were issued in relation to 2009 . The decreased number of permits issued meant lower housing effects on the market in subsequent years, and in the case of reversing the economic downturn, a short-term excess of demand over supply until the moment of enhanced construction.

Compared to 2009, the dynamics of building permits issued in 2013 were higher in Latvia and Lithuania by more than $50 \%$. The dynamics in Portugal and Spain were smallest with a decrease of $70 \%$ compared to 2009 . The fact that there was no sustained upturn in the housing market was evidenced by the number of housing permits.

With the exception of a few countries (Germany, Lithuania, Sweden, Austria, and the UK), this index is still showing a downward trend. Developers built fewer homes, but this did not translate into poor financial results for the largest property development companies. In Poland, the number of housing permits declined during the analyzed period, while it rose in the UK. These are two countries for which the discussed indices had different trends and will be subject to further detailed analysis (Table 2).

\section{Polish and British Construction and Housing Market}

\section{Trends in the British Market}

The UK is an exemplary European market where, despite the property market downturn, the previously discussed construction sector indices were improving. The building production index in the UK, after a period of decline, had been growing since 2009 despite the crisis. In 2014, a markedly greater number of companies in the industry assessed the market positively (The Construction Index 2014b). This change in 
Table 2 Selected indices of the construction market and the housing market in Poland and the UK (2009-2013)

\begin{tabular}{lll}
\hline Variable & Poland & United Kingdom \\
\hline Building production index & increase & increase \\
Owner, with mortgage or loan & increase & decrease \\
Tenant, rent at reduced price or free of charge & stagnation & increase \\
Building permits - number of dwellings & decrease & increase \\
Construction Index & decrease & increase \\
House Price Index & decrease & increase \\
\hline
\end{tabular}

Source: Compilation by the author based on Eurostat data (Eurostat European Commission 2015)

companies' attitudes occurred in the last quarter of 2013, but the indicator (The Construction Index 2014b) did not exceed in this period the 2005 peak in the last ten years.

Construction firms are relatively undercapitalized compared with firms across the rest of the UK economy, ${ }^{3}$ which threatens their investment ability and imposes the necessity to use bank loans in new ventures (Peiser and Frey 2003). Analyses of selected financial results for the six largest property development companies in the UK market indicated their excellent standing in 2009-2012. One can note revenue growth in each of these companies and falling profits in only three out of six cases. The ranking of the largest UK developers in the housing market, however, were considered on the capital market as a good investment (Table 3).

This trend indicated signs of improvement in the building contracting market and is a good forecast for the housing market. In contrast, the house prices index (UK Halifax Index) indicated an upturn in the housing market in the first quarter of 2013, but only in the third quarter of 2014 did it exceed the values from the beginning of 2007 (The Construction Index 2014b, UBS 2015). Good performance of property developers in the UK market outdid the upward movement of the property price index, which means that the recovery of the property market was secondary in relation to the developers' results.

\section{Recovery of the Polish Residential Property Market}

Analysis of the economic situation in the construction industry in Poland shows that more operators still evaluate the market negatively than those that do so positively (Foryś 2011). Nevertheless, this gap has been narrowing since 2012 (Główny Urząd Statystyczny 2014). The last two years have observed changing attitudes of building contractors, whose financial results also improved in the second quarter of 2014. Over $60 \%$ of building contractors were profitable with an average rate of return of $1.6 \%$, while the rate of return in 2013 was $2.3 \%$.

A specific barometer for the property development sector in Poland is the WIGDEV index, created on the basis of performance of property development companies listed on the WSE. It is a total return index that calculates the shares of property

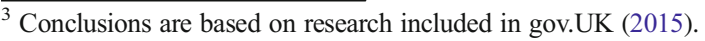


Table 3 Selected indices of the largest residential property developers in the UK in 2009-2012

\begin{tabular}{lcccr}
\hline Company & 2009 & 2010 & 2011 & 2012 \\
\hline Revenue of the six biggest construction companies & in the UK (£m) & & \\
Balfour Beatty & 9.486 & 10.339 & 10.473 & 11.035 \\
Carillon & 5.206 & 5.629 & 5.139 & 5.051 \\
Laing O'Rurke & 3.603 & 3.526 & 3.313 & 3.545 \\
Interserve & 1.800 & 1.907 & 2.315 & 2.320 \\
Morgan Sindall & 2.548 & 2.214 & 2.102 & 2.227 \\
Kier & 2.374 & 2.146 & 2.099 & 2.179 \\
Profit of the six biggest construction companies in the UK (£m) & & 246 \\
Balfour Beatty & 270 & 267 & 201 & 143 \\
Carillon & 116 & 136 & 168 & 23 \\
Laing O'Rurke & 81 & 50 & 30 & 67 \\
Interserve & 80 & 8 & 64 & 40 \\
Morgan Sindall & 62 & 45 & 41 & 66 \\
Kier & 63 & 25 & 58 & \\
\hline
\end{tabular}

Source: The Construction Index (2014a)

development companies and includes income from dividends. Preemptive rights are also taken into account. The base date of the index was 15 June 2007, and the index value on that day amounted to $6,543.82$ points. A drastic decline in the index value occurred in the second half of 2007 and reached its lowest value in the third quarter of 2008. After a period of growth, a renewed decline was recorded mid-2011, where its achieved level of 1000-2000 points has remained. In 2013 and 2014 the index value was more stable, although at a very low level (Foryś and Tarczyńska-Łuniewska 2015).

Good financial results of the best property development companies on the WSE did not correspond to their poor performance in the stock market, which will be examined later in this paper. Stock exchange performance of property development companies is, however, consistent with the low values of the hedonic house price index set by the Polish National Bank (Narodowy Bank Polski) (NBP). The house price index in Poland, points to the continuing downward trend in prices. In the last two years, even the improvement in optimism of construction companies was not positively correlated with the house price index values. In the last quarter of 2014, it reached the lowest level in its history since the beginning of 2007, when it was officially published. In order to demonstrate that the economic and financial condition of property development companies was better than indicated by their performance on the stock exchange, information from the Polish stock market was used.

\section{Research Methodology}

\section{Fundamental Analysis of Listed Companies}

The performance of property development companies listed on the WSE can be assessed by fundamental analysis. Its purpose is to examine the economic standing of 
a company with a goal of conducting its market valuation (Tarczyński et al. 1997). The fundamental analyses takes into consideration macroeconomic analyses as well as sector analysis and general company health. The market valuation focuses on economic and financial indicators of business performance, liquidity, profitability and liabilities. ${ }^{4}$

The comparison of indices allows investors to rank the listed companies. However, the evaluation of a company in reference to the others is usually made having just one index or one group of indices describing the same financial result in mind. A complex evaluation of companies described with many variables and their rankings is useful when assessing their investment potential. It also helps to determine the stability of ranking over time and to answer the question of whether or not their results stem from the market situation and to what extent the fundamental evaluation of the sector reflects the share prices.

\section{Linear Ordering Method}

Multivariate analysis was used to analyze the data. The process of identifying homogeneous groups can be based on cluster analysis or by using values of a synthetic measure (Helwig 1968; Zeliaś 2000). Determining the rank of an item against the background of others permits evaluation of investment attractiveness (Tarczyński 1994; Tarczyński 1997; Tarczyński and Łuniewska 2006; Łuniewska 2005) and compares development potential using methods of linear ordering (Batóg 1997).

The tool of linear ordering is the synthetic measure of development (SMD), determined for each researched item provided that the assumptions of linear ordering are met. The subject of analysis is a non-empty and finite set of items substantively related to the research. The variables are presented on an ordinal scale, comparable as a result of standardization. Also, there is a synthetic criterion for ordering items, not subject to direct measurement and the ordering relationship is the relationship of most of the values to this index.

The starting point of the multivariate analysis is to construct a set of variables, based on substantive reasons, to identify the availability of statistical data and its credibility. Diagnostic features should be universal and hold widely recognized importance and relevance. In addition, they should be measurable, good quality, interpretable, of varied effect and ensure the cost effectiveness of the research. To evaluate variation, most commonly used are the coefficient of variation (determined for the variables on the ratio scale; a given feature/variable has good variation when the coefficient of variation is $10 \%-15 \%$ ) and skewness (a valid feature is strongly right-skewed). The final selection of variables was preceded by eliminating overly correlated variables. For this purpose, Helwig's parametric method can be used (1968), which, based on correlation matrices of features, allows for discrimination of strongly correlated features. In the procedure, the threshold value $r^{*}$ was used, and $r^{*} \in(0 ; 1)$ is usually equal to 0.5 . In subsequent steps, central variables and isolated variables were determined, forming the base system of the features. The features to be accepted for further analysis can be somewhat arbitrarily selected or the criterion of frequency of the occurrence of a given variable in the database throughout the analyzed period can be used (Zeliaś 2000).

\footnotetext{
${ }^{4}$ Because publications about economic and financial indicators are easily available, the present paper does not include a description of formulas and indices (for details see Altman 1968; Sierpińska and Jachna 2002; Tarczyński 1997; Tsay 2005).
} 


\section{Standardization of Variables}

The next step was to standardize the variables, which involved converting all variables to stimulants. Typical formulas for conversion of destimluants to stimulants are displayed in the following equations (Walesiak 1996):

- ratio

$$
x_{i j}=b \cdot D_{i j}^{-1}, \text { where } b>0 ;
$$

- differential

$$
x_{i j}=a-c \cdot D_{i j}^{-1} \text {, where } c>0 \text {. }
$$

$D_{i j}$ is the value of $j$, the de-stimulant observed in $i$, the item, and $a$ - constant (in special cases $a=0$ or $a=\max _{i}\left\{D_{i j}\right\}, b-$ constant (in special cases $b=\min _{i}\left\{D_{i j}\right\}$ or $\mathrm{b}=1$ ), $c$, the constant (in special cases $b=1$ ). Nominants' conversion to stimulants can be done using equations according to the following formulas:

- ratio

$$
x_{i j}=\left\{\begin{array}{ll}
\frac{N_{i j}}{n_{j}} & \left(N_{i j} \leq n_{j}\right) \\
\frac{n_{i j}}{N_{i j}} & \left(N_{i j}>n_{j}\right)
\end{array},\right.
$$

- diferential

$$
x_{i j}=\left\{\begin{array}{l}
N_{i j}-n_{j}\left(N_{i j} \leq n_{j}\right) \\
n_{i j}-N_{j}\left(N_{i j}>n_{j}\right) .
\end{array}\right.
$$

$N_{i j}$, is the value of $j$, the nominant observed in $i$, the item, and $n_{j}$, is the nominal level of $j$.

\section{Synthetic Measure of Development}

Aggregation of variable values may be based on standard formulas involving the construction of the taxonomic development pattern, which is an item characterized by optimization, due to the purpose of the research values of individual diagnostic features. Existence of a standard-reference item was assumed, against which taxonomic distances of the remaining examined items were determined $q_{i}=d\left(x_{i}, x_{0}\right)$. Determined distances allowed for ordering the examined items from the most developed (positioned closest to the standard-reference) to the least developed (positioned farthest from the standard-reference).

Most often, to measure the distance of a given item from the development model (as a value of synthetic measure), the Minkowski metric was applied, a special case of which is the Euclidean distance:

$$
q_{i}=\left[\sum_{j=1}^{m} \frac{1}{m}\left(x_{i j}^{\prime}-x_{0 j}\right)^{2}\right]^{\frac{1}{2}}, \text { for } i=1,2, \ldots n,
$$

where $x_{i j}^{\prime}$,-normalized values of $j$ the diagnostic variable for $i$ the item. 
Obtained values of the synthetic variable $q_{i}$ were converted, obtaining the synthetic development measure $q_{i}^{\prime}$ for $i$-th item:

$$
q_{i}^{\prime}=\frac{q_{i}}{\|Q\|}, \quad \text { for } i=1,2, \ldots n
$$

where $\|Q\|$, is the norm of a synthetic variable. In practice, formula (6) was transformed, determining $1-q_{i}^{\prime}$, which resulted in the change of variable preference (in the case of stimulants, greater values evidence a higher level of the examined phenomenon). In turn, what was assumed as the $\|Q\|$ norm was most often the maximum value $\|Q\|=\max \left\{q_{i i}\right\}$ or statistical maximum value $\|Q\|=\bar{q}+a \cdot S_{q}$, where $\bar{q}$-skew meant, $S_{q}$ - standard deviation of synthetic variable, $a$, random number determined at such a level so that $q_{i}^{\prime} \in\langle 0 ; 1\rangle$ and $q_{i}>0$. One can also specify such value $a$ so that it satisfies the inequality:

$$
a \geq \frac{q_{\text {imax }}-\bar{q}}{S_{q}},
$$

where $q_{i \text { max }}$ is the maximum value of measure $q_{i}$. Often, value $a=2$ due to the rule of two (or three) standard deviations. Synthetic measures proposed in the literature differed not only in the aggregate function presented above, but also in the standard-reference selection procedure (determination of coordinates) or the mode of normalization of features.

\section{Multivariate Comparative Analysis of the Property Development Companies Listed on the WSE}

\section{Property Development Sector Indices for the WSE Listed Companies}

In the analyzed period, there were 35 property development companies listed on the WSE. Companies selected for the analysis were those that primarily constructed housing projects in Poland and had a long history of listings, which allowed for the economic-financial assessment of companies for two periods: the flourishing economic situation in the real estate market (2007-2008) and the economic downturn years (2009-2013). As a result, 35 companies from the industry portfolio were retained. ${ }^{5}$

Selected economic and financial results of the companies are presented in Table 4. The analysis of the structure of the indices highlighted the extreme asymmetry of these indices in subsequent years of research. As a result, the median values of these indices were presented for the investigated property development companies listed on the WSE.

The obtained profitability ratios in 2007-2008 tended to rise for the net profit margin and return on equity, but the highest and most satisfactory net profit margin $(0.21)$ was obtained in 2008 during the economic upturn in the real estate market. In the last two

\footnotetext{
${ }^{5}$ Alta SA, Altreco SA, Atlas Estates Ltd., BBI Development SA, Celtic Property Developments SA, Dom Development SA, Echo Investment SA, ED Invest SA, Globe Trade Centre SA, J.W. Construction Holding SA, KCI SA, LC Corp SA, Octava SA, Polnord SA, Triton Development SA and Wikana SA.
} 
researched years, 2012 and 2013, and especially in 2013, all profitability ratios confirmed the poor condition of property development companies. One reason for the poor condition of the companies was due to the high value turnover ratio, three times higher in 2013 than 2007, when the real estate market experienced a boom.

The poor condition of the developers listed on the WSE in 2013 was evidenced by the lowest analyzed period current liquidity ratio (1.94) and the working capital ratio (nearly 10 times lower in 2013 compared to 2007). The debt ratio, 0.33, was not an alarming value because of the nature of the activity carried out by property development companies, although its lowest level (0.14) can be noticed in 2010 during the ongoing crisis. This was driven by banks tightening credit activity, reducing risk of recourse to foreign resources by developers, consumption of profits earned in the economic upturn years (2007-2009), and, in the case of large property development companies, diversifying investments in real estate markets being generically different in the following year.

To sum up the condition of the analyzed property development companies, poor results were observed in 2013, which did not coincide with the extremely negative assessment by stock market investors (WIG-DEV) or a more optimistic value of the index of the general climate of the economic situation in the construction sector. Discrepancies in the results could be explained by differing behavior in the property development company market between those with large capital employing hundreds of workers with multi-year contracts, and those small operators consisting of several people and operating in local, more predictable real estate markets. The next section discusses a group of property development companies that achieved better or worse results and should therefore be more attractive or more risky for capital market participants (Gitman and Joehnik 1984).

\section{Synthetic Measure of Development for the Property Development Sector}

An analysis was performed for the Polish market, which showed the behavior of capital market investors compared with the financial performance of the companies. The procedure for selecting variables for grouping, described above, helped to determine eight economic and financial variables that were used to determine the synthetic measure of development (SMD).

In the first group of variables (profitability ratios), three ratios were suggested for the analysis: net profit margin, return on equity and return on assets. In the second group (liquidity ratios), the following remained: working capital and current liquidity ratio. In the third group (activity ratios), two variables remained: amount due turnover and liabilities turnover. The fourth group (debt ratio) included only one variable, debt margin. As a result, the SMD indicators were calculated for the investigated companies in subsequent years (Table 5).

The next step comprised of ranking the companies from the most distant from the standard reference to the least distant. The classification of companies in subsequent years confirmed high and stable positions from 2007 to 2013 at Dom Development SA and ED Invest SA, regardless of the economic environment and the business cycle in the property market (Table 6).

Annual rates of return were determined for the investigated companies. Apart from three, Triton, Polnord and EdInvest, the remaining companies indicated uniform courses of rates of return on the WSE. All were characterized by decreased rates of return in 2011, not supported by such bad financial results compared to previous 
Table 4 Selected economic and financial indices of property development companies listed on the WSE

\begin{tabular}{|c|c|c|c|c|c|c|c|}
\hline Ratios & 2007 & 2008 & 2009 & 2010 & 2011 & 2012 & 2013 \\
\hline \multicolumn{8}{|l|}{ Profitability Ratios } \\
\hline Net profit Margin (\%) & 20.15 & 20.51 & 13.12 & 19.93 & 14.60 & 4.08 & 8.04 \\
\hline $\begin{array}{l}\text { Return on Equity } \\
\text { (ROE) }(\%)\end{array}$ & 3.29 & 3.97 & 1.22 & 3.33 & 2.17 & 1.54 & 0.34 \\
\hline $\begin{array}{l}\text { Return on Assets } \\
\quad(\text { ROA })(\%)\end{array}$ & 2.87 & 2.20 & 1.21 & 2.54 & 1.03 & 0.56 & -0.69 \\
\hline \multicolumn{8}{|l|}{ Liquidity Ratios } \\
\hline $\begin{array}{l}\text { Working Capital } \\
\text { (PLN th.) }\end{array}$ & 79,883 & 22,996 & 44,313 & 60,955 & 109,368 & 35,394 & 7860 \\
\hline Current Ratio & 2.14 & 2.13 & 3.35 & 3.24 & 3.23 & 3.22 & 1.94 \\
\hline \multicolumn{8}{|l|}{ Activity Ratios } \\
\hline $\begin{array}{l}\text { Amount Due } \\
\text { Turnover }\end{array}$ & 81 & 71 & 38 & 76 & 112 & 197 & 240 \\
\hline Liabilities Turnover & 189 & 101 & 214 & 347 & 344 & 430 & 321 \\
\hline \multicolumn{8}{|l|}{ Debt Ratios } \\
\hline Debt Margin & 0.20 & 0.23 & 0.24 & 0.14 & 0.26 & 0.30 & 0.33 \\
\hline
\end{tabular}

Source: Calculations by the author based on Notoria Serwis (2014)

financial years. Only the best classified, due to financial indices Dom-Development, reached the smallest decline in rates of return, especially in 2011.

In 2007, the lowest negative rate of return was characterized by Triton $(-0.014)$, while the best results were obtained by Polnord ( 0.01$)$. The increase in rates of return of all companies in 2009 is a result of the economic situation in the construction sector and real estate market. LCCORP recorded the highest return (0.019), and Polnord recorded the lowest (0.001). The negative rates of return in 2011 for all the analyzed companies are the result of a deepening recession in the property market, linked to the economic downturn. The most severe decline in rates of return were recorded by the JW Construction (-0.02), and by Dom Development (-0.007). In 2013, only a few companies achieved positive returns (Alta, Dom Development, Echo Investment, JW

Table 5 SMD indices of analyzed property development companies listed on the WSE

\begin{tabular}{llllll}
\hline Designation & Company & 2007 & 2009 & 2011 & 2013 \\
\hline ALTA & Alta SA & 0.16 & 0.00 & 0.00 & 0.14 \\
DOMDEVEL & Dom Development SA & 0.34 & 0.24 & 0.50 & 0.36 \\
ECHO-INV & Echo Investment SA & 0.19 & 0.10 & 0.32 & 0.30 \\
ED-INVEST & ED Invest SA & 0.17 & 0.29 & 0.48 & 0.05 \\
JW-CONST & JW. Construction SA & 0.26 & 0.07 & 0.36 & 0.05 \\
LCCORP & LC Corp SA & 0.00 & 0.03 & 0.23 & 0.20 \\
POLNORD & Polnord SA & 0.25 & 0.18 & 0.20 & 0.12 \\
TRITON & Triton Development SA & 0.10 & 0.07 & 0.30 & 0.30 \\
\hline
\end{tabular}

Source: Calculations by the author based on Notoria Serwis (2014) 
Table 6 Classification of analyzed property development companies listed on the WSE, 2007-2013

\begin{tabular}{llll}
\hline 2007 & 2009 & 2011 & 2013 \\
\hline LCCORP & AALTA LTA & ALTALTA A & JW_JW_CONST T \\
TRITON & LCCORP & POLNORD & ED_INVEST \\
ALTA & TRITON & LCCORP & POLNORD \\
ED_INVEST & JW_CONST & TRITON & ALTA \\
ECHO_INV & ECHO_INV & ECHO_INV & LCCORP \\
POLNORD & POLNORD & JW_CONST & ECHO_INV \\
JW_CONST & DOMDEVEL & ED_INVEST & TRITON \\
DOMDEVEL & ED_INVEST & DOMDEVEL & DOMDEVEL \\
\hline
\end{tabular}

Source: Author's classifications

Construction, LCCORP), while three companies (ED Invest, Polnord Triton) continued to have negative rates of return. Such results do not show clear evidence of change in trend in the real estate market.

Low rates of return on the WSE did not correspond to financial results of the companies in the investigated years, which proved the fundamental analysis of companies was not a relevant criterion for investors on the stock exchange investing in property development companies. While the obtained economic and financial results of developers may have suggested an upturn in the sector, the behavior of stock market investors did not confirm a direction of change in the housing market.

\section{Conclusions}

The analysis of the housing market and the related property development market in the EU countries does not permit the conclusion that the economic downturn in the sector has already passed. Although there are countries in which the values of the indices suggest an improvement in the housing market, these are not yet permanent changes. Additionally, one can notice that the environment of the property development sector differs across the EU. The EU countries did not respond in a uniform way to negative signals from the capital market.

Despite the fact that their largest companies performed well during the unfavorable period for the real estate market, the confidence of investors in this sector is limited, as shown with the Polish market. Arguments that could support predicting a quick way out of the crisis on the real estate market cannot be specified.

Similarly, financial indices for the property development industry (fundamental analysis) do not correspond to the performance of property development companies on the WSE, as evidenced by indices of companies in this sector and low rates of return on these securities. It can be assumed that since the current economic crisis has its roots in the banking sector, the first signs of recovering must also be sought in this sector.

The answer to the question asked in the introduction is negative. Share prices of listed property development companies (technical analysis) are a poor indicator of their factual performance. Negative rates of return reported by companies enjoying good economic and financial results (e.g., the ones generating profits) provide a sufficient 
argument in favor of the fundamental analysis. Both the obtained financial indices and the synthetic measure of development indicate large investment potential of the property developers listed on the WSE, despite the sluggish WIG-DEV index.

As the downturned property market, which started in the second half of 2008, was the first to have a global range, it is difficult to compare the obtained results with previous economic crises. Another difficulty in formulating conclusions about the investors' assessments of companies and, consequently, the share prices is a free movement of speculative capital which implies that the conclusions concerning one local market must take into account investors' strategies on other markets (Chinmoy et al. 1997). As a result, a complete analysis of the relationship between the performance of property development companies and the situation in any real property market would have to include an analysis of this sector for all related capital markets.

Open Access This article is distributed under the terms of the Creative Commons Attribution 4.0 International License (http://creativecommons.org/licenses/by/4.0/), which permits unrestricted use, distribution, and reproduction in any medium, provided you give appropriate credit to the original author(s) and the source, provide a link to the Creative Commons license, and indicate if changes were made.

\section{References}

Al-Malkawi, H. A. N., \& Pillai, R. (2013). The Impact of Financial Crisis on UAE Real Estate and Construction Sector: Analysis and Implications. Humanomics, 29(2), 113-135.

Altman, E. I. (1968). Financial ratios, discriminant analysis and the prediction of corporate bankruptcy. The Journal of Finance, 23(4), 589-609.

Batóg, J. (1997). Proposal for Classification of Companies According to the Economic and Financial Situation. Taksonomia, 4, 68-79.

Bordo, M., Eichengreen, B., Klingiebiel, D., \& Martinez-Peira, M. S. (2000). Is Crisis Problem Growing More Severe? Economic Policy. A European Forum, No. 32.

Chinmoy, G., Guttery, R. S., \& Simans, C. F. (1997). The Effects of the Real Estate Crisis on Institutional Stock Prices. Real Estate Economics, 25(4), 591-614.

Eurostat European Commission (2015). Construction production index in the European Union from www. appsso.eurostat.ec.europa.eu. Accessed 2 May 2015.

Foryś, I. (2011). Social and Economic Determinants of the Housing Market Development in Poland. Szczecin: University of Szczecin Scientific Publishing.

Foryś, I., \& Tarczyńska-Łuniewska, M. (2015). The Economic and Financial Analysis of Development Companies During the Real Estate Recession. Research Papers University of Szczecin No 862, Szczecin, pp. 459-474.

Gitman, L. J., \& Joehnik, M. D. (1984). Fundamentals of Investing. New York: Harper \& Row.

Global Asset Management UBS (2014). Real estate - All you need to know. Retrieved from www.ubs. com/realestate. Accessed 12 Dec 2014.

Główny Urząd Statystyczny GUS (2014). The index of the general climate of the economic situation in the construction sector in Poland from www.stat.gov.pl. Accessed 15 Dec 2014.

GOV.UK (2015). Trade Credit in the UK Construction Industry: An Empirical Analysis of Construction Contractor Financial Positioning and Performance. BIS Research Paper, No 118, Department for Business Innovation \& Skills. From www.gov.uk/government/publications/trade-credit-in-the-ukconstruction-industry. Accessed 29 March 2015.

Helwig, Z. (1968). The Use of the Taxonomic Method to the Typological Division of Countries Due to Their Level of Development and the Structure of Assets and Qualified Staff. Statistical Revive, (4), 307-327.

Łuniewska, M. (2005). Sectoral Synthetic Measures of Development In Security Analysis. Research Papers of Wrocław University of Economics No 1076, Wrocław, pp. 210-219.

Minsky, H. (1986). Stabilizing an Unstable Economy. London: Yale University Press. 
Narodowy Bank Polski NBP (2015). House price index in Poland, 2007-2014. From https://www.nbp. pl/publikacje/rynek_nieruchomosci/ceny_mieszkan_03_2015.pdf. Accessed 29 March 2015.

Notoria Serwis. (2014). Vol. 3/2014.

Peiser, R. B., \& Frey, A. B. (2003). Professional Real Estate Development. Washington, D.C.: ULI The Urban Land Institute.

Peto, R. (2011). Global Property Outlook and Role of Real Estate in the European Financial Crisis. Real Estate, 36(2), 11-20.

Sierpińska, M., \& Jachna, T. (2002). Company rating by world standards. Warszawa: Wydawnictwo Naukowe PWN.

Tarczyński, W. (1994). Taxonomic Measure of the Attractiveness of Investments in Security. Statistical Revive, 41(3), 275-300.

Tarczyński, W. (1997). The Efficiency of Warsaw Stock Exchange Activity. Ekonomista, (4), 521-538.

Tarczyński, W., \& Łuniewska, M. (2006). Multidimensional Comparative Methods on the Capital Market. Warszawa: PWN Publishing.

The Construction Index (2014a). Construction Market Data Retrieved- Top 20-house-builders in 2012 from http://www.theconstructionindex.co.uk/news/view/us-construction-ends-2104-on-six-year-high. Accessed 15 Dec 2014.

The Construction Index (2014b). House Price Index in the United Kingdom from http://www. theconstructionindex.co.uk/news/view/us-construction-ends-2104-on-six-year-high. Accessed 15 Dec 2014.

Tsay, R. S. (2005). Analysis of financial time series, No 543. New York: Wiley.

UBS (2015). Real estate - All you need to know from www.ubs.com/realestate. Accessed 2 May 2015.

Walesiak, M. (1996). Methods of Analysis of Marketing Data. Poland: PWN Warszawa.

Zeliaś, A. (2000). Taxonomic analysis of spatial differentiation standard of living in Poland in dynamic terms. Kraków: Cracow University of Economics Publishing. 